\title{
Salon
}

\section{Reefer madness}

O tudies have suggested that as many as $I$ in 4 cannabis users may be genetically at risk for developing schizophrenia or a related psychotic disorder. Now, a new study reveals all users are at risk. ${ }^{1}$

Given recent United Nations' statistics citing Canada as the industrial world's leading consumer of cannabis, this news should set alarm bells ringing. After all, a leading role in cannabis consumption sets the stage for a leading role in psychotic disorders. Instead, Canada's mainstream media responded in chorus from The Happy Hippy Hymn Book, failing to notice that it is ro years out of date.

"Legalizing pot makes sense," intoned a National Post editorial earlier this summer, while a Globe and Mail article entitled "The True North Stoned and Free" giggled about Canada's "little pot habit."

Schizophrenia, a severe form of psychosis, is a brain disorder that typically produces delusions, hallucinations, paranoia, disturbances in problem solving, memory and concentration, along with depressed mood, anxiety and social withdrawal. Its causes are not fully understood though environmental stressors (e.g., childhood trauma, neglect) are thought to interact with genes to produce disruptions in brain chemistry. Longitudinal and other studies demonstrate that cannabis, at potencies much greater than Ig6os' varieties, is one of those stressors and that with their rapidly developing brains, the young are particularly vulnerable to developing psychosis later in life. The younger the user and the higher the potency of marijuana's active ingredient, tetrahydrocannibol, the greater the risk.

In 2005, I interviewed the pre-eminent authority on marijuana and psychosis, Professor Robin M. Murray. The Dunedin Birth Cohort Study, in which he had participated, and which involved over 1037 participants from Dunedin, New Zealand, over 3 decades, had just been published. ${ }^{2}$ ป Murray explained how genes and marijuana could interact to increase risk of developing psychosis. The catechol-Omethyltransferase (COMT) gene, consisting of a MET ("normal") type and a VAL ("abnormal") type, metabolizes dopamine, a brain chemical that produces

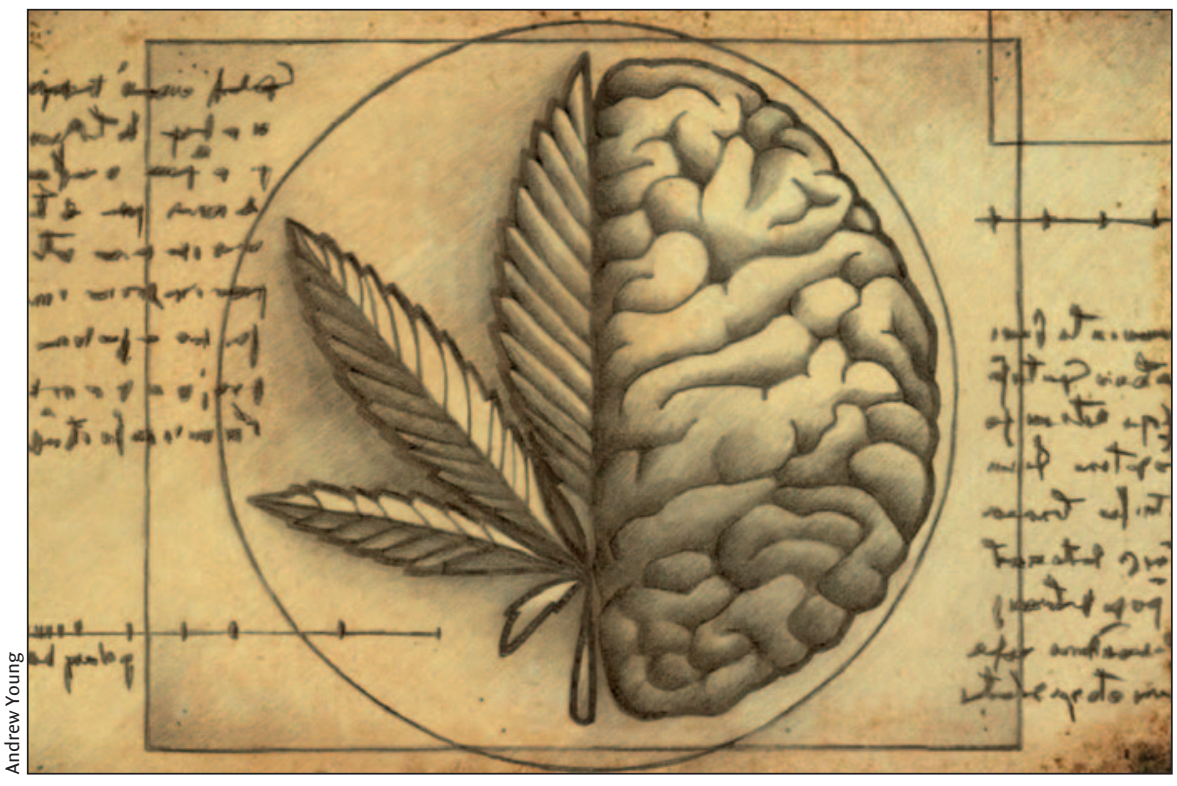

the "highs" characteristic of drug and alcohol use. A MET/VAL mixture increases risk 2-fold. A VAL/VAL mixture increases risk Io times. A quarter of the population is VAL/VAL, he later explained during an interview entitled "Cannabis and our genes" with BBC TV's Panorama.

Lead and co-author of countless studies as well as co-editor of Marijuana and Madness, Murray is head of the Division of Psychological Medicine and professor of psychiatry at King's College Institute of Psychiatry in London. He has been a vocal critic of British government policy that ignores the mental health issues associated with marijuana use. In May, the Institute organized its second conference on cannabis and mental health.

According to a recent study, $14 \%$ of British patients with schizophrenia could have avoided the illness if they had not used cannabis. ${ }^{1}$ This meta-analysis also reveals that while the issue of whether cannabis causes psychosis remains unclear, the risk of developing psychosis from cannabis use by the general population, irrespective of age or genes, is 4I\%. For heavy users - defined as daily or weekly - the risk is in the range of $50 \%$ to $200 \%$.

In 2004, the Canadian Addiction Survey found that $22 \%$ of all male and 10\% of all female respondents aged $5_{5}^{-24}$ use cannabis on a weekly or daily basis.

However you approach the math, it adds up to a disturbing result.
The news isn't all bad. Canada's marijuana decriminalization bill was withdrawn in 2005, and now Health Minister Tony Clement is launching an anti-drug campaign. For the medical and other communities, however, the work is just beginning. Lobbying governments, informing the media, gathering relevant Canadian data and educating families are only a small part of what needs to be done. "Experts are now agreed on the connection between cannabis and psychosis," Professor Murray told USA Today. "What we need now is for I4-year-olds to know it."

\section{Margret Kopala}

\section{REFERENCES}

I. Moore THM, Zammit S, Lingford-Hughes A, et al. Cannabis use and risk of psychotic or affective mental health outcomes: a systematic review. Lancet 2007;370:319-28.

2. Caspi A, Moffitt T E, Cannon M, et al. Moderation of the effect of adolescent-onset cannabis use on adult psychosis by a functional polymorphism in the catechol-O-methyltransferase gene: Longitudinal evidence of a gene $X$ environment interaction. Biol Psychiatry 2005;57:1117-27.

Margret Kopala writes columns for the Ottawa Citizen.

Have you got an opinion about this article? Post your views at cmaj.ca. Potential Salon contributors are welcome to send a query to salon@cma.ca 